\title{
TEACHING ENGLISH READING ABILITY FOR SECOND/FOREIGN LANGUAGE LEARNERS
}

\author{
Leffi Noviyenty \\ State Islamic Institute of Curup, Indonesia \\ leffinoviyenty@gamil.com
}

\begin{abstract}
This article discusses the factors that affect the teaching of reading skills in English, for which the learners of English is the second language (L2) or as a foreign language (FL) and the alternative activities that may be done on the learning process in order to achieve the goals of effective reading learning. There are seven teaching principles that are needed to be considered and developed by reading teachers in the classes of English as second or foreign language. The seven principles of instruction should be applied in designing the reading class of English as a foreign language. The implementation of the seven principles will further optimize the students' reading ability in reading class of English as a foreign language for the students.
\end{abstract}

Keywords: learning principles; reading skills; second/foreign languages.

\section{Introduction}

The purpose of teaching English reading is to develop student's competence in reading skills which covers the basic standard of competence in Curriculum-Based Competence (CBC). For university students, reading is the key to gain as much knowledge as possible. Thus, it is important for reading lecturers to create a comfortable reading atmosphere in the class not only by asking the students to read or checking their understanding but also recognizing their conditions. For quite long, teaching reading in STAIN English Study Program tends to only force students to read and do the tasks based on the text. Consequently, most students are only able to do the reading task without mastering the way to transfer the reading skills when they are faced other reading texts.

As students, especially in reading subject, perhaps we have experienced learning to read in a language that is not our native or dominant language. As lecturer, we should bring a certain amount of knowledge to the students. We are supposed to teach reading, either in the students' native language (L1) or in their second or foreign language (L2/FL). In Indonesia, English acts as a foreign language. We learn English in formal education. McWhorter states that people take English to fulfil their purposes, such as 
to run education, to get job, and others and English reading is one of the skills in learning to reach those purposes ${ }^{1}$.

The limitation of knowledge about teaching L2/FL reading is the real problem. It creates a limitation of teaching activity. In L1 reading, the students have the ability to read in their own native language, and they have knowledge about what reading is, even though they may no longer be conscious of what they do when they read or how they learned to read. Furthermore, they have been students in classes where the teacher helps them learn how to read. Reading in the L1 (first language) shares numerous important basic elements with reading in the L2 (second language) or FL (foreign language), and the process also differ significantly. Some studies show that reading proficiency in an L1 has little influence on reading proficiency in an $\mathrm{L} 2 / \mathrm{FL}$; others show that there is a correlation between the two. These two aspects should be considered by L2 reading teacher because they will affect the process and the result of teaching reading itself.

In fact, formal reading class is one of the students' opportunities to get the basic knowledge about reading skills which further should be applied in their studying for every subject, not only for English department students but also other departments. A proverb says that "Reading is a window of the world". Besides, reading class is also a moment for them in order to get used with English reading. Moreover, by following reading class actively, the students can comprehend the strategy in understanding English reading and develop their reading abilities. It is a phenomenon that most of the students only use reading class to read English texts. It can be assumed that if there is no reading class, the students almost do not read English reading. In other word, there are only several students who use their time to read English sources outside the class. By maximizing the function of reading class effectively, students are forced to read. It is the first step to make them accustomed to do it, even though it needs time and a long process in order to make reading become their habit. These reasons show how important English reading class for students.

Based on the realities of teaching $\mathrm{L} 2 / \mathrm{FL}$ reading and some reasons of the importance of English reading class, this article tries to discuss the six factors that influence reading in an L2/FL: cognitive development, language proficiency in L1, metacognitive knowledge, language proficiency in L2, degree of differences between L1 and L2, and cultural orientation. This article will also try to elaborate four principles of designing the reading course: goals and objectives, approaches, materials and evaluation. This article is expected to be beneficial to build an effective, useful, and comfortable reading class based on the students' need, not only for academic purposes but also for wider purposes.

\section{Six factors that influence reading in an L2/FL}

The reading demands of college students are wide and diverse. Textbooks, the student's primary reading material, represent unique academic disciplines. Each differ in style, content and conceptual complexity. In STAIN, the students should also read literatures about Islam religion as the primary sources. The reality that the students come from different background of high schools, not only from Islamic high schools and they are different in English language 
level proficiency should become considerations for lecturers in order to create an effective, useful and comfortable reading class. Grabe notes that students begin reading in an L2/FL with a different knowledge base that they had when starting to read in their $\mathrm{L}^{2}$. He also states that most $\mathrm{L} 1$ readers know several thousand words before they begin to read, and they have some ability to handle the basic grammar of their own language. L2/FL readers have neither of those advantages. Furthermore he notes a variety of conditions that may influence the L2/FL reading: Some are illiterate in their first language, some have little experience reading for academic purposes, some may not transfer abilities fro their L1 to the L2/FL, and most try to read texts that are beyond their level of L2/FL proficiency. Aebersold proposes four factors that influence reading in an L2/FL; they are grammatical competence, sociolinguistic competence, discourse competence and strategic competence ${ }^{3}$. From those theories above, we have a list of factors that influence reading in L2/FL:

- Cognitive development and cognitive style orientation at the time of beginning L2/FL study

- Language proficiency in the L1

- Metacognitive knowledge of L1 structure, grammar, and syntax

- Language proficiency in an L2/FL

- Degree of difference between the L1 and an L2/FL (writing systems, rhetorical structure, appropriate strategies)

- Cultural orientation

By considering these factors, teacher can develop some ideas to maximize the $\mathrm{L} 2 / \mathrm{FL}$ reading class. Those aspects can be presented as in the following diagram: 


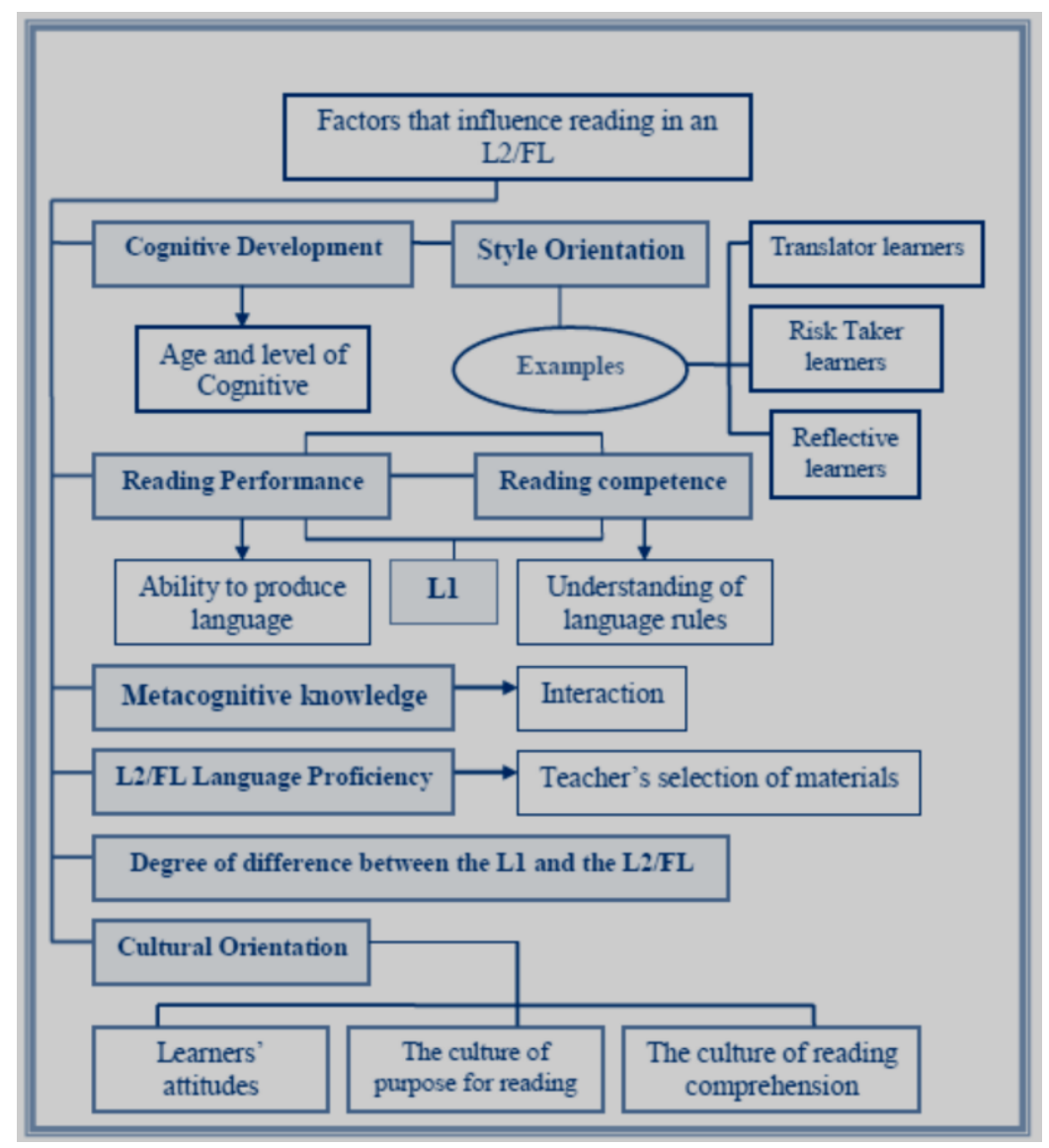

\section{Cognitive Development and Style Orientation}

Reading teachers, however, have little control over cognitive or mental development levels at the time of beginning L2/FL. L1 and L2 reading use different underlying cognitive processes. Hatch argues that different learning strategies, reading levels, world knowledge between L1 and L2 are influence by the age of the learner, and can influence the success of language learning ${ }^{4}$. College students has passed the critical period of age an arrived at mature age. However, cognitive is beyond teacher's control.

Each student brings a preferred style, whether consciously or unconsciously, to the learning process. For example, the reflective learner tends to think about new information and process it carefully before going on to the next text. In contrast, a risk taker might make a guess and go to a new task without much reflection. The students whose style has always been to translate every word in a text will have a difficult time adjusting to skimming and scanning exercises. Skilled teachers have to be careful observe and need to know as much as possible abut the behaviours of their students.

\section{Reading Performance and Competence in the $\mathrm{LI}$}

Aebersold concludes that there is a transfer of reading skills from the L1 to an $\mathrm{L} 2 / \mathrm{FL}$ and that teaching reading in the native language may facilitate the transfer ${ }^{5}$. Skilled teachers should be able to improve the transfer process so that the students in L2/FL reading do not repeat the same knowledge of 
reading. Teachers must try hard to use the students' competence in the L1 to increase their ability in the L2/FL. It can be done by teaching the basic knowledge of L2/FL reading, whether its competence - understanding the language rules, or its performance ability to produce language. The writer sees that the teachers' improvement can be started from motivating the students to use their competence in the L1 to increase their L2 reading in combination with how to perform it. So competence and performance are used together. For instance, do not only ask the students to answer the questions from the text by using the appropriate tenses, but also train them to use their memory about the text, make them produce their own sentence whether in written form or orally.

\section{Metacognitive Knowledge}

Aebersold defines metacognitive knowledge as the students' ability to discuss, describe, give rules for, and comment on L1 language use ${ }^{6}$. The writer sees the point of metacognitive knowledge is interactive. Teachers need to observe the relationships among the students all. Variety activity and classroom setting in every meeting can motivate the students interact each other and decrease the boring situation. Ask the students to work in small groups or pairs to discuss the concept, compare experiences, and develop ideas, encourage them to cooperate and collaborate. To some extent, the group takes pressure off the individual learner and places responsibility on the collective. By working through the problem in the less threatening environment of the group, individual learners gain confidence and use the L2/FL more than they would dare to in front of the whole class. It is true that working with student groups is time consuming, but students learn well and enjoy learning in these situations.

Brown $^{7}$ states some principles
for designing interactive reading
techniques:

1. Techniques should be intrinsically motivating

2. techniques should utilize authentic language and contexts

3. encourage the development of reading strategies

4. include both bottom-up and topdown techniques

5. consider subdividing your techniques into pre-reading, duringreading, and after-reading phases

6. build in some evaluative aspects to your techniques.

\section{L2/FL Language Proficiency}

L2/FL readers will not be able to read as well in the foreign language as in their first language until they have reached a threshold level of competence in that foreign language. This should be considered by the teacher in keeping the balance of what the students have already taken and what they will take. Language proficiency also influences the teachers' selection of materials for the reading class. The materials should be suitable to the level of their competence. For instance, college students in the first semester who have got structure 1, and not yet writing 1 , should be considered to have the first step beginner for reading text. For the next semester when they have already got structure 2 and writing, the materials for reading should be a step more difficult. Nunan notes that the materials should always be $\mathrm{N}+1$ or one step more difficult than before ${ }^{8}$. However, it is also important to avoid the frustration and despair that arise from constantly being required to tackle 
L2/FL reading texts that are far beyond the students' language competence.

Other examples of considering students' language proficiency are, giving pre-reading activity to the students at the beginning and lowintermediate levels of L2/FL proficiency - even though these lowintermediate students come to a text with different degree of knowledge about the text, their knowledge of the $\mathrm{L} 2 / \mathrm{FL}$ is minimal to nonexistent - and sometimes letting them use their fist language in order to facilitate them to learn the L2/FL. But when there is an opportunity to introduce a phrase or word in the L2, teachers must interject the $\mathrm{L} 2 / \mathrm{FL}$ as the discussion progress in the L1. This activity can also be done for the same reasons as students with higher levels of language proficiency.

\section{Degree of Difference between the L1 and the L2/FL}

Wallace explains that "Languages may be so different in the way they represent meaning in their written form that there is, arguably, no generalization from the first to the target language" . The greater the differences between the native language and the target language, the more difficult it is to acquire the target language and to become a proficient reader in it.

English language which is as a foreign language in Indonesia has more complex rules than Bahasa Indonesia as native language (L1). Teachers can use the differences as comparison to simplify the explanation of the lesson. In reading, fortunately, Bahasa Indonesia has identical contents of knowledge. For example, paragraph which consists of topic sentence, supporting sentences, and concluding sentence -, punctuation and their functions, and others. Many foreign vocabularies, including English words, enrich Bahasa Indonesia vocabularies. The idea of context clues in English reading is almost the same as in Bahasa Indonesia. However, there are differences such as in sentence structure, reference and of course the language itself. However, the strategy in teaching L2/FL should be innovated to the more suitable one, not only imitating the teaching of L1.

\section{Cultural Orientation}

Understanding the types of reading skills and strategies appropriate in the L2/FL based on the cultural orientation is also one of factors that influence successful reading in an L2/FL. College students need the skills and strategies for success in an academic situation, such as being able to read long texts efficiently, being able to infer meaning, being able to interpret and understand ambiguity, and being able to recognize implicit meaning in texts.

The culture in doing reading itself should be a consideration too for the teachers. It is reality that students in Indonesia spend very little time to read not only in L1 reading moreover in L2/FL reading. Teacher needs some tricks so that the students are accustomed to reading, particularly for L2/FL reading. For instance, ask the students read any readings that interest them, and then report to the class in the form of essay, story or report. By this way the students are given a large opportunity to use their language performance.

From the textbooks and the assignments given by teacher in reading subject, it seems the culture of reading comprehension in Indonesia is the ability to do the exercises correctly. This can be seen from the way teacher 
evaluates the students' comprehension. Most of teachers tend to give question and answer, multiple choices, true false, synonyms. Those kinds of tasks only limit the students' creativity in describing their comprehension. Aebersold describes some cultural orientation from several countries about reading class: international students who come to study in United States Re often surprised at the lengthy reading assignments they receive in a history or literature class; American students abroad are amazed at the level of detail that is expected of them in university settings ${ }^{10}$. In some cultures, comprehension means the ability to explain the grammar and structure of page of text; in others it means the ability to summarize the thesis and argument of a whole book in a few sentences.

\section{The application of the six factors into the designing of reading course}

From the six factors that influence reading in an L2/FL above, and general description of reading class, teachers can design the L2 reading class more effective for academic success and for wider purposes. In general, there are preparations need to be made before the teacher enters the reading class, as in the following diagram:

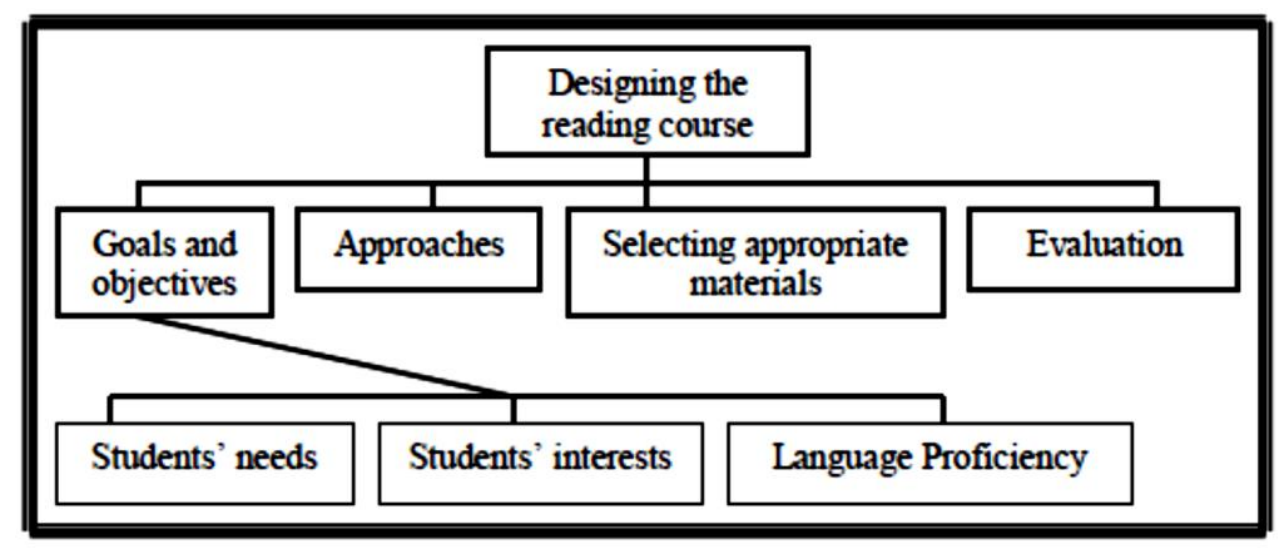

\section{Goal and Objectives}

Stating goals and objectives are not new things for teachers. For years, curriculum provides some guidance and also the suitable materials. Goals are broad, general statements about what students will achieve during the semester/class. Objectives are specifically stated aims that teachers use in creating individual lesson plan. Teachers need to put more attention on how to keep on focus on these goals and objectives during the semester. Be consistent and sure that the results of these goals will be achieved by the students.

The latest curriculum Competence-Based Curriculum - provides a large opportunity for teachers in deciding the goals, objectives and materials in teaching, but the idea is based on the students' need. Aebersold suggests that goals and objectives are better stated and must arise directly from students' needs, interests, and abilities ${ }^{11}$. Teachers were not accustomed to doing this. Perhaps, they find difficulty in gaining the information about them. Most reliable way finding out what students think they need is to ask them. Variety of ways can be used to collect information about students' need: questionnaires, individual interviews or oral reports, observation of small group discussions and survey. Furthermore, survey is one easy and useful way to collect 
information which consists of questions for students to answer. Involving students in establishing purposes for reading will make them understand why they are in a reading class. By taking into account both teacher-perceived and students' contributed need when planning reading goals, teachers and students work together to build a learning environment that is relevant to both.

The involvement of students is also needed in specific lessons. The students' reception of activities and their comments about activities serve as a guide to their needs and interests. Teacher can share the responsibility for learning and the power of planning with their students. For example, students could decide what strategies they want the class to explore with certain reading texts. By doing this, students are not only developing their knowledge of how to approach a text in the L2/FL but also their confidence in doing so.

Students' interest is also needed as a contribution in deciding goals. In the background of this paper, from the writer's experience, it is possible that very few students have needs that motivate them to read in the L2/FL. However, probably all have interests that could be used to propel them into reading in the L2/FL. The more interested students are, the more they will persevere in reading. Even, intense interest motivates people to read materials that are beyond their range of language proficiency.

The other consideration is language proficiency. There are varieties of language proficiencies among the students in one class. It is a great challenge for teachers to build multiple lesson plans and a range of materials to address all the students by using variety of performances.

\section{Approaches to Teaching Reading}

Richards and Rodgers define approach as "theories about the nature of language and language learning that serve as the source of practices and principles in language teaching" ${ }^{\prime 2}$. So far, we have already known two main approaches to teaching reading. The first is intensive approach which currently reigns in most L2/FL classrooms and books. The second is extensive approach which mostly gives freedom to the students to choose materials based on their needs and interests or their language proficiency.

Intensive approach is the basic needs for L2/FL students. By this approach, students do intensive reading with the help from teachers. Students practise the theories of reading intensively. Perhaps the text used is limited but the point is how to exercise students in comprehending them. Skilled teachers should create exercises which can cover a broad range of reading skills. They should consider the appropriate method to be used which is suitable to the condition of students' language proficiency, and needs. Task and setting or classroom arrangements also take role. For college students as adult learners, teachers should always create and modify more flexible class arrangements to avoid boring situation or monotonous environment which is an ordinary case in reading class. One of the ways to create variety include using various modes, the use of free, openended activities versus highly structured activities, and the used of student group and collaborative learning. Variety in reading classes is virtually unlimited. The secret to using variety in activities is to balance the old and the new, or the known and the unknown, in order to keep students mentally working toward the objectives of the class. Classroom 
interaction such as pair work, small group work, whole class, should perform changeably. This classroom interaction must always be monitored by teacher to avoid students spend time during the class with unrelated things to the lesson. Here the teacher acts more as observer and facilitator.

Since the theories of reading comprehension need to be developed and the students' knowledge must be improved, a wider opportunity to practise those theories by using unlimited sources is needed. Extensive reading is one of the opportunities, Teacher uses extensive approach and he can monitor the students' reading by asking them to report what they have read in the form of essay, report, description, and others. Because these activities need a lot of time, teacher can use them as students' homework for every meeting. Besides, extensive reading can motivate students to make reading as their habits and students need to know that they can read effectively on their own, without a teacher there to make all the decisions for them. That confidence comes only from experience of having tried it on their own and having been successful most of the time.

In conclusion, teachers better use an approach which is integrated from a combination of intensive and extensive approach in every meeting.

\section{Selecting Appropriate Materials}

It is suggested that in selecting appropriate materials, teachers refer to the goals and approach in teaching. In extensive approach, besides letting the students choose the materials by themselves freely, sometimes teachers need to interrupt it by deciding the topic, the length of text, kind of text and the way students report their reading.
Sources such as magazines, newspapers, articles, and many others are recommended. In other side, in intensive approach where teachers mostly take role in selecting materials, textbook seems to be the only source. The most common type of L2/FL textbook teaches reading with a mixture of intensive and extensive approaches and contains both informational and story/narrative texts written in modified language. Each text has accompanying exercises that develop the use of reading strategies, vocabularies and sometimes grammar comprehension. Other kind of textbook is reading skills textbook which focus on the development of various reading strategies, such as skimming, scanning, finding main ideas of the paragraph, summarizing and other skills. For the beginning and intermediate levels of L2/FL there are often found series textbooks which the heavy emphasis is on grammar and vocabulary. Reading skill practice may be limited.

Selecting appropriate materials are including selecting appropriate topics in reading. Nowadays, if we take a close look at some topics in reading, brings us to the idea that some of them have been selected on the basis of the importance of the knowledge for its own sake instead of its communicative value for the learners. They seem to be well familiar. Using such reading materials as presented, the best that the teacher can do is teaching reading no more for information, but for language use. The teacher would creatively ask comprehension that encourages students' imagination, projection, inference, or even extrapolation but still based on the information in the text as the basis. It is self-evident that in order for the teacher to be able to take advantage out of incompatible materials, the teachers have to master a 
set of skill-using, some of which are unprecedented, or no more than skillgetting.

Authentic materials are suggested. They can be taken directly from L1 sources and are not changed in any way before they are used in the classroom. Articles or advertisements from an L2/FL newspaper and train schedules are examples of authentic materials. Modified materials are also permitted to allow students whose L2/FL proficiency is below that of the original text to read the text with sufficient understanding to comprehend the message. Authentic materials are better started from students' daily life to the wider aspects.

\section{Evaluation}

All decisions about how to evaluate student progress toward meeting course goals should be made before the course begins. Furthermore, the decisions - whether teacher will evaluate the students during the class or only at the end of the semester - should be made in concert with the course goals and the approach used in teaching the course. So far, the criteria to evaluate the students in reading class depend on how far that the students can do the exercises correctly. It happens almost in all level of students' language proficiency. If the test which is given at the end of semester, as the final test, uses different text from the students get in every meeting, it means teacher only evaluate the student reading competence in that meeting. In fact, teacher needs to evaluate the students reading performance too. It is true that tests are one option. If a teacher has decided that he is going to use only tests to determine if course goals and evaluative outcome statements have been met, then the entire course grade will depend upon test scores. If, however other evaluate tasks are used during the course, those should be factored into the final course grade. Some reading teachers also like to put some criteria of evaluation outside the tests, such as class participation, homework, or attendance. The important thing is to make sure that the evaluation really evaluates the students' achievement in reading, not only as formal evaluation.

The traditional methods of testing reading are multiple-choice questions, cloze tests (students are asked to supply words that have been deleted from a reading text where the teacher determines the key words), completion tasks, short answer and open-ended questions, and contextualized or authentic tasks. Aebersold mentions that there are some guidelines to help the process of evaluation ${ }^{13}$ :

- Keep the course objectives clearly in mind at every step

- Carefully match the test to what is to be tested

- Recognize the potential for bias and variation

- Design the test to assess what the students know

Experience is the best teacher for constructing assessment plans, and regular evaluation of the plan is the best critic. The best assessment, whether alternative or traditional, is integrated into the course and becomes an important part of the instructional process. The assessment provides the feedback that every teacher needs in the classroom.

\section{Conclusion}

Reading in a second or foreign language is a dynamic and interactive process in which learners makes use of background knowledge, text schema, lexical and grammatical awareness, L1related knowledge, and real-world knowledge as well as their own personal 
purposes and goals, to arrive at an understanding of written material. Teacher of reading in an L2/FL must understand the factors that influence their students' reading processes. L2/FL reading teachers who can recognize these factors at work are better equipped to help their students. Those factors are cognitive development and style orientation, reading performance and competence in the L1, metacognitive knowledge, language proficiency in $\mathrm{L} 2 / \mathrm{FL}$, degree of difference between the L1 and the L2/FL, and cultural orientation. By using the six factors which influence students' reading processes as the guidance, the teacher can design a better reading course for academic successes or the wider purposes. Designing a reading course that will further students' knowledge and abilities demands that the course designer and the teacher keep many relevant points in mind so that the students will learn in the best possible way.

Designing a reading course in general, concerns with deciding goals and objectives, using the suitable approach in teaching reading, selecting appropriate materials, and making decision how to evaluate the students progress. These aspects should be applied in making the lesson plans.

\section{Catatan Akhir:}

1 T. McWhorter, Kathleen. Guide to College Reading. Toronto: Little, Brown Company, 1986, p. 233

2 Grabe, W. "Factors that influence reading in an L2/FL". In Aebersold, J. A. From Reader to Reading Teacher: Issues and Strategies For Second Language Classroom. New York: Cambridge University Press, 1988, p. 23
3 Aebersold, J. A. From Reader to Reading Teacher: Issues and Strategies for Second Language Classroom. New York: Cambridge University Pres, 1997, p. 23

4 Hatch, E. M. Psycholinguistics: A Second Language Perspective. Rowley, MA: Newbury House, 1983, p. 45

5 Aebersold, J. A., op. cit., p.24

6 ibid., p. 26

7 Brown, H. D. Teaching by Principles: An Interactive Approach to Language Pedagogy. Englewood Cliffs: Prentice Hall, Inc, 1994, p. 298

8 Nunan, D. Understanding Language Classroom: A guide for Teacherinitiated Action. New York: Prentice Hall, 1989, p. 53

9 Wallace, C. Reading. New York: Oxford University, 1992, p. 11

${ }^{10}$ Aebersold, J. A., op. cit., p. 29

11 ibid., p. 36

12 Richards, J. C., \& Rodgers, T. S. Approaches and Methods in Language Teaching: A Description and Analysis. New York: Cambridge University Press, 1986, p.16

${ }^{13}$ Aebersold, J. A., op. cit., p.50

\section{Reference}

Aebersold, J. A. 1997. From Reader to Reading Teacher: Issues and strategies for Second language Classroom. New York: Cambridge University Press.

Brown, H. D. 1994. Teaching by Principles: An Interactive Approach to Language Pedagogy. Englewood Cliff: Prentice Hall, Inc. 
Grabe, W. 1988. "Factors that influence reading in an $\mathrm{L} 2 / \mathrm{FL} "$. In Aebersold, J. A. From Reader to Reading Teacher: Issues and strategies for Second Language Classroom. New York: Cambridge University Press.

Hatch, E. M. 1983. Psycholinguistics: A Second Language Perspective. Rowley, MA: Newbury House.

Richards, J. C, \& Rodgers, T. S. 1986. Approaches and Methods in Language Teaching: A Description and Analysis. New

York: Cambridge University Press.

T. McWhorter, Kathleen. 1986. Guide to College Reading. Toronto: Little, Brown Company.

Nunan, D. 1989. Understanding Language Classroom: A Guide for Teacher-initiated Action. New York: Prentice Hall.

Wallace, C. 1992. Reading. New York: Oxford University. 